\title{
An Outbreak of Gastroenteritis Associated with Astrovirus Serotype 1 in a Day Care Center, in Rio de Janeiro, Brazil
}

\author{
AMV Silva, EG Leite, RMS Assis, S Majerowicz, JPG Leite ${ }^{+}$ \\ Laboratório de Virologia Comparada, Departamento de Virologia, Instituto Oswaldo Cruz-Fiocruz, \\ Av. Brasil 4365, 21045-900 Rio de Janeiro, RJ, Brasil
}

Between June 4th and June 20th 1996 rotavirus, adenovirus, and astrovirus (HAstrV) were investigated in fecal samples from 27 children under three years old with acute diarrhea, attending the Bertha Lutz day care center, in Rio de Janeiro. All fecal samples were analyzed by polyacrylamide gel electrophoresis (PAGE), reverse transcriptase polymerase chain reaction (RT-PCR), enzyme immunoassays (EIA), and electron microscopy (EM). Nine of them (33\%) showed positive results for HAstrV by at least one of the employed methodologies. Eight were positive by RT-PCR and EIA, and six by EM. All positive samples were inoculated onto HT-29 (human colon adenocarcinoma) cultured cells for HAstrV isolation and seven were positive after three passages. The sequencing analysis of eight RT-PCR products (449 bp) from gene that codifies VP2 protein, showed a total nucleotide identity among them and 98\% with HAstrV-1 (strain Oxford type 1). This is the first report of a gastroenteritis outbreak associated with HAstrv-1 in a day care center in Rio de Janeiro and it reinforces the importance of this virus in association with infantile acute gastroenteritis.

Key words: astrovirus - gastroenteritis - outbreak - Rio de Janeiro - Brazil

Astroviruses are plus-sense single-stranded RNA (ssRNA) viruses with $28 \mathrm{~nm}$ in diameter without a phospholipid envelope. Some viral particles show a star-like morphology by electron microscopy (EM) and recently were classified as belonging to the Astroviridae family (Monroe et al. 1994). Astroviruses have been isolated from human as well as from animal species. Eight human serotypes of astroviruses (HAstrV 1-8) have been described and the HAstrV-1 is the most prevalent strain (Kakizawa et al. 1997).

The medical importance of HAstrV was established when they were found to be the second most common cause of viral diarrhea in young children (Matsui \& Greenberg 1996). HAstrV infection induces a mild watery diarrhea during two or three days, associated with other symptoms like vomiting, fever, anorexia and abdominal pain. Usually HAstrV infects young children, although gastroenteritis outbreaks associated with HAstrV involving older children, elderly people, and immunocompromised patients have been described (Matsui \& Greenberg 1996).

\footnotetext{
This work was supported by Fiocruz, CGLAB/MS, $\mathrm{CNPq}$, Faperj and Capes.

${ }^{+}$Corresponding author. Fax: +55-21-2598-4491. E-mail: jpgleite@ioc.fiocruz.br

Received 14 February 2001

Accepted 11 July 2001
}

In Brazil, there are few reports describing HAstrV infections (Nozawa et al. 1985, Leite et al. 1991, Stewien et al. 1991, Timenetsky et al. 1993, Tanaka et al. 1994) and all of them have used EM only for virus detection.

In this report, we describe for the first time an outbreak of gastroenteritis associated with HAstrV-1 in a day care center, in Rio de Janeiro, using different methodologies for virus characterization.

\section{MATERIALS AND METHODS}

Fecal specimens - Fecal specimens were obtained from 27 children under three years old with acute diarrhea. These specimens were collected at Bertha Lutz day care center, Oswaldo Cruz Foundation (Fiocruz), Rio de Janeiro, between June 4th20th, 1996. Fecal suspensions (10\%) were prepared in $10 \mathrm{mM}$ Tris, $1 \mathrm{mM} \mathrm{Ca}^{++}, \mathrm{pH} 7.2$, homogenized by vortexing, clarified at $3.000 \mathrm{xg}$ for $10 \mathrm{~min}$ at $4^{\circ} \mathrm{C}$ and stored at $-20^{\circ} \mathrm{C}$ until analysis.

Enzyme immunoassays - Initially, all fecal suspensions were screened for rotavirus and adenovirus using an enzyme immunoassay for group A rotavirus and adenovirus (EIARA) (Pereira et al. 1985). The test was carried out according to the manufacturer's protocol (Bio-Manguinhos, Fiocruz, Ministry of Health, Brazil).

A commercial qualitative enzyme immunoassay (ELISA) (IDEIA ${ }^{\mathrm{TM}}$ Astrovirus) for detection of HAstrV from fecal suspension was performed following the recommendations of the manufacturer 
(DAKO Diagnostics Ltd, Denmark).

A non-commercial enzyme immunoassay (EIA), previously described by Noel et al. (1995), was performed to detect HAstrV from supernatants of the infected HT-29 (human colon adenocarcinoma) cells (3rd passage).

RNA extraction - Five hundred $\mu \mathrm{l}$ of $10 \%$ fecal suspensions were submitted to RNA extraction using the glass powder methodology described by Boom et al. (1990).

Polyacrilamide gel electrophoresis - The polyacrylamide gel electrophoresis (PAGE) and silver staining methodologies were used to investigate the presence of segmented dsRNA viruses as previously described by Pereira et al. (1983).

Reverse transcription followed by polymerase chain reaction - The RT-PCR for HAstrV was carried out as previously described by Noel et al. (1995). Distilled milli-Q water was used as negative control in ssRNA extraction and in RT-PCR procedure. HAstrV-2 used as positive control was kindly provided by Dr SS Monroe, Viral Gastroenteritis Section, Enteric Respiratory Virus Branch, Centers for Disease Control and Prevention, Atlanta, GA, USA.

All manipulation recommended for PCR procedures were carried out as a precaution to avoid false positive results (Kwok \& Higuchi 1989).

Electron microscopy - Fecal suspensions (10\%) were treated with $2.45 \mathrm{M}$ ammonium sulfate $(\mathrm{v} / \mathrm{w})$ and negatively stained with $2 \%$ phosphotungstic acid (pH 7.2) as described by Barth (1998). The grids were observed in a Zeiss EM-900 electron microscope, at magnification of 50,000X.

Isolation of HAstrV in HT-29 cells - HAstrV isolation was attempted from all positive samples by EM, RT-PCR and/or EIA by inoculation in HT29 cells, which were kindly supplied by Dr Francisco Candal, Cell Cultural Development Section, Biological Products Branch, Centers for Disease Control and Prevention, Atlanta, GA, USA.

The cells were propagated in Dulbecco's Medium supplemented with antibiotics (penicillin 100 $\mathrm{U} / \mathrm{ml}$ and streptomycin $100 \mu \mathrm{g} / \mathrm{ml}$ ), $2.5 \mu \mathrm{g} / \mathrm{ml}$ fungizon (DMS), and $10 \%$ fetal bovine serum (FBS) (Life Technologies, Inc. Gaithersburg, MD, USA). Two hundred-fifty $\mu \mathrm{l}$ of $10 \%$ fecal suspensions were treated with $20 \mu \mathrm{l}$ antibiotics for $30 \mathrm{~min}$ at room temperature, homogenized by vortexing and clarified at $16.000 \mathrm{X} \mathrm{g}$ for $5 \mathrm{~min}$ at $4^{\circ} \mathrm{C}$. Two hundred $\mathrm{ml}$ of treated supernatants were mixed with equal volume of DMS containing $5 \mu \mathrm{g} / \mathrm{ml}$ of trypsin (SigmaAldrich Co. St. Louis, MO, USA) and inoculated onto confluent HT-29 monolayer cells, previously washed twice with $3 \mathrm{ml}$ of DMS without FBS. The adsorption was carried out for $60 \mathrm{~min}$ at $37^{\circ} \mathrm{C}$, then the supernatants were discarded and $5 \mathrm{ml}$ of DMS with $2 \%$ of FBS were added. The cells were incubated at $37^{\circ} \mathrm{C}$ for $18 \mathrm{~h}$ and a new fresh DMS containing $10 \mu \mathrm{g} / \mathrm{ml}$ of trypsin were added. After that, monolayer were incubated for five days at $37^{\circ} \mathrm{C}$. Subsequently, cultures were harvested by freezing/thawing $\left(-70 / 37^{\circ} \mathrm{C}\right)$ three times and submitted a two consecutive passages.

Sequencing of RT-PCR astrovirus amplicons The RT-PCR products of eight positive samples were sequenced using the Prism Ready Reaction Dye Deoxy Terminator Cycle Sequencing Kit (Applied Biosystems, Inc, USA) following the protocol described by Noel et al. (1995) and an ABI 377 automatic sequencer (Applied Biosystems, Inc., USA). Sequence data from both strands of the RTPCR products were aligned and compared using the GCG program of the Staden sequence analysis package (Dear \& Staden 1991). The data were compared with the other HAstrV sequences by using the University of Wisconsin, Genetics Computer package of programs (Devereux et al. 1984).

Bacteriological and parasitological investigations - The bacteriological and parasitological investigations were carried out following the protocols described by Edwards and Ewing (1996), Neves (1995), and Lima (1995), respectively.

\section{RESULTS}

Laboratorial findings - From 27 fecal samples analyzed by EM, RT-PCR and IDEIA ${ }^{\mathrm{TM}}$ Astrovirus, nine $(33 \%)$ were positive by at least one methodology and five presented positive results for all applied methodologies (Table). No other enterophatogen was detected by the methods routinely used for investigation of bacteria, parasites, and rotavirus and adenovirus, characterizing an outbreak of acute gastroenteritis associated with HAstrV.

In a group of nine positive samples, eight were detected by RT-PCR showing the expected 449bp fragment (Fig. 1). One sample was positive by IDEIA $^{\mathrm{TM}}$ Astrovirus only (Table). As shown in Fig. 2, typical HAstrV particles were visualized in 6 out of 27 samples (22\%) analyzed by EM.

Nine positive samples were inoculated onto HT29 cells and seven of them (78\%) were positive by a non-commercial EIA, after the third passage.

The sequencing analysis of the RT-PCR products (nt 4526 to nt 4974, VP2 region) from eight isolates showed a nucleotide identity of $100 \%$ among them and 98\% with HAstrV-1 (strain Oxford type 1) (data not shown).

Epidemiological and clinical findings - HAstrV were detected only in children under two years old (5 to 20 months), although the 27 fecal samples were obtained from children ranged between 5 to 32 months. 
TABLE

Detection of astrovirus in nine fecal samples by different methodologies

\begin{tabular}{ccccc}
\hline RT-PCR & $\begin{array}{c}\text { ELISA, IDEIA } \\
\text { DAKO }\end{array}$ & EM & $\begin{array}{c}\text { Isolation into } \\
\text { HT-29 cells } a\end{array}$ & $\begin{array}{c}\text { Number of } \\
\text { positive samples }\end{array}$ \\
\hline+ & + & + & + & 5 \\
+ & + & + & - & 1 \\
+ & - & + & 1 \\
+ & - & - & + & 1 \\
- & + & - & - & 1 \\
\hline Total & 4 & 2 & 3 & 9 \\
\hline
\end{tabular}

$a$ : supernatants analyzed by EIA (Noel et al. 1995); (+) positive; (-) negative

The major clinical symptoms observed during the outbreak were: vomiting, fever $\left(37.5-38^{\circ} \mathrm{C}\right)$, abdominal pain, inappetence, cough, coryza and mucus on feces. The symptoms associated with diarrhea persisted for three to six days.

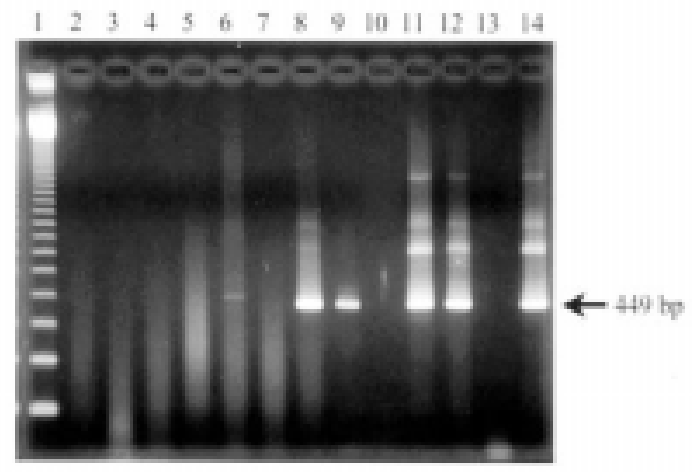

Fig.1: detection of genomic RNA segment of astrovirus (HAstrV) by RT-PCR from fecal samples. Line 1: MW 123bp Ladder (Life Technologies, Inc); lines 2-5, 7, 10: negative stool samples; lines $6,8,9,11,12$ : positive stool samples; lane13: negative control; lane 14: HAstrV-2 positive control

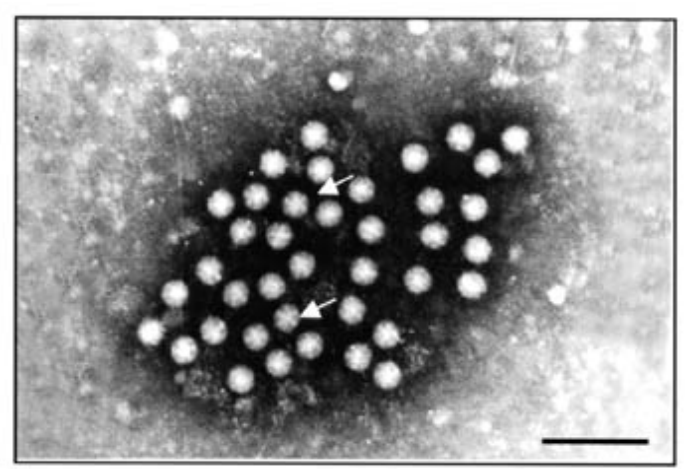

Fig. 2: electron micrograph of astrovirus (HAstrV) particles from sample LVC426. Arrows are indicating typical morphology of HAstrV. Bar $=100 \mathrm{~nm}$

\section{DISCUSSION}

The development of specific assays with higher sensitivity have been established the role of HAstrV as agent of gastroenteritis in young children, as well as in both elderly and immunocompromised patients (Mitchel et al. 1993, Jonassen et al. 1995, Mustafa et al. 2000). In order to characterize the etiological agent responsible for the outbreak of gastroenteritis at Bertha Lutz day care, different methodologies for virus, bacteria, and parasite detection, were employed. HAstrV-1 was the only enterophatogen detected in this outbreak, with a positive rate of $33 \%$. This is the first gastroenteritis outbreak associated with HAstrV-1 in a day care center reported in Rio de Janeiro, Brazil. Other outbreaks in the same day care center, occurring during 1996 and 1997, were investigated, but HAstrV were not detected. During the same period, HAstrV were detected in sporadic infections among hospitalized children, demonstrating the circulation of those viruses in Rio de Janeiro (Silva et al. unpublished observations).

RT-PCR and ELISA (IDEIA ${ }^{\mathrm{TM}}$ Astrovirus) were equivalents to detected HAstrV. However, the positivity of one sample just by IDEIA ${ }^{\mathrm{TM}}$ Astrovirus, suggests: (i) the presence of defective particles in a lower concentration than EM sensitivity; (ii) a false positive result. Despite the small number of samples, all methods used in that investigation showed to be satisfactory to detect HAstrV. As suggested by Glass et al. (1996), the RT-PCR and EIA should be the methods of choice for HAstrV detection, since RT-PCR have been increased the viral detection in stool samples.

Although outbreaks associated with several HAstrV serotypes have been described (Oishi et al. 1994, Belliot et al. 1997), HAstrV-1 is the most prevalent serotype circulating worldwide (Noel et al. 1995, Shastri et al. 1998, Medina et al. 2000).

In Brazil, reports have demonstrated the occurrence of HAstrV at low frequencies (2-5\%). The use of the EM as the only methodology for virus 
detection could explain the low rate of detection and the lack of information about the circulating HAstrV types (Nozawa et al. 1985, Leite et al. 1991, Stewien et al. 1991, Timenetsky et al. 1993, Tanaka et al. 1994). However, in a study carried out among inpatient children, we detected different serotypes of HAstrV circulating at higher rate (15\%) (Silva et al. unpublished observations).

At Bertha Lutz day care center all positive samples were detected from children between 5 and 20 months. Our data corroborate the findings reported by Mendes (1997) during a serosurvey study conducted in Belém, Brazil, when it was demonstrated that HAstrV seropositivity rates increased from $13.9 \%$, at 6 months of age to $64.9 \%$ in children up to 2 years old, suggesting that HAstrV infection is more frequent than the previously reported (Nozawa et al. 1985, Leite et al. 1991, Stewien et al. 1991, Timenetsky et al. 1993, Tanaka et al. 1994).

The molecular epidemiology of HAstrV remains to be elucidated in Brazil and further investigations should provide the answer as to the role of individual serotypes in outbreaks in day care centers, elderly houses, and inpatients clinics. This would be achieved by performing molecular epidemiology of both common and uncommon serotypes.

\section{ACKNOWLEDGEMENTS}

To Drs R Glass, S Monroe, and G Belliot for providing reagents and sequencing support, Alexandre Fialho for technical assistance, and Biogen Com. \& Distrib. Ltda to supply IDEIA ${ }^{\mathrm{TM}}$ Astrovirus kit. To the staff of Bertha Lutz Day Care for providing the samples, to the Department of Bacteriology, IOC, and Laboratory of Parasitology, HEC, Fiocruz, for performing the respective analysis.

\section{REFERENCES}

Barth OM 1998. Contrastação negativa. In W de Souza, Técnicas Básicas de Microscopia Eletrônica Aplicadas às Ciências Biológicas, Sociedade Brasileira de Microscopia, Rio de Janeiro, p. 45-56.

Belliot G, Laveran H, Monroe SS 1997. Outbreak of gastroenteritis in military recruits associated with serotype 3 astrovirus infection. J Med Virol 51: 101106.

Boom R, Sol CJA, Salimans MMM, Jansen CL, Wertheim-van Dillen PME, Van der Noordaa J 1990. Rapid and simple method for purification of nucleic acids. J Clin Microbiol 28: 495-503.

Dear S, Staden R 1991. A sequence assembly and editing program for efficient management of large projects. Nucl Acids Res 19: 3907-3911.

Devereux J, Haeberli P, Smithies O 1984. A comprehensive set of sequence analysis programs for the VAX. Nucl Acids Res 31: 165-169.

Edwards PR, Ewing WH 1986. Identification of Enterobacteriaceae, 4th ed., Elsevier, New York, 529 pp.

Glass RI, Noel JS, Mitchell D, Herrmann JE, Blacklow
NR, Pickering LK, Dennehy P, Ruiz-Palacios G, De Guerreiro ML, Monroe SS 1996. The changing epidemiology of astrovirus-associated gastroenteritis: a review. Arch Virol 12: 287-300.

Jonassen TO, Kjeldsberg E, Grinde B 1995. Detection of human astrovirus serotype 1 by the polymerase chain reaction. $J$ Virol Meth 44: 83-88.

Kakizawa J, Ushijima H, Wen L, Ikeda Y, Oseto M 1997. Genetic analysis of the capsid region of human astrovirus serotype 3 isolated in Japan. Microbiol Immunol 41: 637-640.

Kwok S, Higuchi P 1989. Avoiding false positives with PCR. Nature 339: 237-238.

Lee TW, Kurtz JB 1981. Serial propagation of astrovirus in tissue culture with the aid of tripsin. J Gen Virol 57: 421-424.

Leite JPG, Barth OM, Schatzmayr HG 1991. Astrovirus in faeces of children with acute gastroenteritis in Rio de Janeiro, Brazil. Mem Inst Oswaldo Cruz, 86: 489490.

Lima JD 1995. Sarcocytis, Isospora e Cryptosporidium. In DO Neves, Parasitologia Humana, 9th ed., Atheneu, Rio de Janeiro, São Paulo, Belo Horizonte, p. 188-197.

Matsui SM, Greenberg HB 1996. Astroviruses. In BN Fields, DM Knipe, PM Howley, RM Chanock, TP Monath, JL Melnick, B Roizman, SE Straus (eds), Virology, Lippincott-Raven Publishers, Philadelphia, p. 811-824.

Medina SM, Gutierrez MF, Liprandi F, Ludert JE 2000. Identification and type distribution of astrovirus among children with gastroenteritis in Colombia and Venezuela. J Clin Microbiol 38: 3481-3483.

Mendes YG 1997. Soroepidemiologia do Vírus Norwalk e do Astrovírus em Crianças de Belém, Pará, Brasil, MSc Thesis, Universidade Federal do Pará, Belém, $97 \mathrm{pp}$.

Mitchell DK, Van R, Morrow AL, Monroe SS, Glass RI, Picering LK 1993. Outbreaks of astrovirus gastroenteritis in day care centers. J Ped 123: 725-732.

Monroe SS, Carter MJ, Herrmann JE, Kurtz JB, Matsui SM 1994. Astroviridae. In Sixth Report of the Internacional Committee on the Taxonomy of Viruses, p. 364-367.

Mustafa, H, Palombo EA, Bishop RF 2000. Epidemiology of astrovirus infection in young children hospitalized with acute gastroenteritis in Melbourne, Australia, over a period of four consecutive years, 1995 to 1998. J Clin Microbiol 38: 1058-1062.

Neves DP 1995. Exame parasitológico de fezes. In DO Neves, Parasitologia Humana, Atheneu, Rio de Janeiro, São Paulo, Belo Horizonte, p. 485-495.

Noel JS, Lee TW, Kurtz JB, Glass RI, Monroe SS 1995. Typing of human astrovirus from clinical isolates by enzime immunoassay and nucleotide sequencing. $J$ Clin Microbiol 33: 797-801.

Nozawa CM, Vaz MGS, Guimarães MAAM 1985. Detection of astrovirus-like in diarrheic stool and its coexistence with rotavirus. Rev Inst Med Trop São Paulo 27: 238-241.

Oishi I, Yamazaki K, Kimoto T, Minekawa Y, Utagawa E, Yamazaki S, Inouye S, Grohmann GS, Monroe 
SS, Stine SE, Carcamo C, Ando T, Glass RI 1994. A large outbreak of acute gastroenteritis associated with astrovirus among students and teachers in Osaka, Japan. J Infect Dis 170: 439-443.

Pereira HG, Azeredo RS, Leite JPG, Andrade ZP, de Castro L 1985. A combined enzyme immunoassay for rotavirus and adenovirus (EIARA). J Virol Meth 10: 21-28.

Pereira HG, Azeredo RS, Leite JPG, Barth OM, Sutmoller F, de Farias V, Vidal MN 1983. Comparison of polyacrylamide gel electrophoresis (PAGE), immuno-electron microscopy (EM) and enzymeimmunoassay (EIA) for the rapid diagnosis of rotavirus infection in children. Mem Inst Oswaldo Cruz 78: 483-490.

Stewien KE, Durigon EL, Tanaka H, Giglio EG, Balcacci
ER 1991. Ocorrência de astrovírus humanos na cidade de São Paulo, Brasil. Rev Saúde Pública 25: 157158.

Shastri S, Doane AM, Gonzales J, Upadhyayula U, Bass DM 1998. Prevalence of astroviruses in a children's hospital. J Clin Microbiol 36: 2571-2474.

Tanaka H, Kisielius JJ, Ueda M, Glass RI, Joazeiro PP 1994. Intrafamilial outbreak of astrovirus gastroenteritis in São Paulo, Brazil. J Diar Dis Rev 12: 219221.

Timenetsky MCST, Kisielius JJ, Grisi SJFE, Escobar AMU, Ueda M, Tanaka H 1993. Rotavirus, adenovirus, astrovirus, calicivirus e "small round virus" em fezes de crianças, com e sem diarréia aguda, no período de 1987 a 1988, na grande São Paulo. Rev Inst Med Trop São Paulo 35: 275-280. 
1074 Outbreak Gastroenteritis Astrovirus 1 - AMV Silva et al. 